\title{
Endocrine involvement in granulomatosis with polyangiitis
}

\author{
Salem Bouomrani*, Mayada Ben Hamad, Nesrine Regaieg, Nesrine Belgacem and Safa Trabelsi \\ Departments of Internal Medicine, Military Hospital of Gabes, Tunisia
}

\begin{abstract}
Endocrine involvement during the course of GPA is exceptional, and only a few sporadic observations were reported. Thus the exact meaning of endocrinopathies associated with this vasculitis is not yet well known. Fortuitous association or specific localization of vasculitis in the endocrine glands? The purpose of this minireview is to study the endocrine involvement in granulomatosis with polyangeiitis and to discuss its possible pathogenic mechanisms.
\end{abstract}

\section{Introduction}

Granulomatosis with PolyAngiitis (GPA), formerly known as Wegener's granulomatosis, is a necrotizing vasculitis of small- and medium-sized vessels associating diffuse inflammation of the vascular wall and peri- and extra-vascular granulomatosis. In its generalised/ systemic form, the GPA associates an ear, nose and throat (ENT), pulmonary and renal involvement with typically a rapidly progressive necrotizing glomerulonephritis with extracapillary crescents, while the absence of renal damage at the time of diagnosis defines the limited forms of GPA whose prognosis is better [1,2].

Antineutrophil cytoplasmic antibodies (ANCA) type cytoplasmic (c-ANCA) with specificity for proteinase 3 (PR3) are of great contribution to the diagnosis of this affection. They are found in more than $90 \%$ of generalised forms and about $50 \%$ of limited forms $[1,2]$.

In the absence of treatment, GPA is a serious disease whose evolution is constantly towards death. Corticosteroids and immunosuppressors have completely changed this prognosis. Endocrine involvement associated with GPA is exceptional, and only a few sporadic observations were reported. Thus the exact meaning of endocrinopathies occurring during the course of this vasculitis is not yet well known. Fortuitous association or specific localization of vasculitis in the endocrine glands?

\section{Endocrine disorders during GPA}

Endocrine disorders during GPA are far dominated by central diabetes insipidus, of which about 10 cases are reported in the literature $[3,4-6]$. This is secondary to granulomatous infiltration of the posthypophysis and/or the pituitary stalk. The observation of Khalifa $\mathrm{M}$ et al. [4] confirmed this by showing an increase in the size of the pituitary gland and the infundibulum and a disappearance of the spontaneous hypersignal of the posthypophysis.

This central diabetes insipidus may be the first clinical manifestation of GPA as illustrated by the two observations of Al-Fakhraoui A et al. [7], and some authors estimate the frequency of pituitary involvement during the course of GPA at 1\% (in the series of 819 cases of GPA of the French Vasculitis Study Group) [8] to 1.3\% (in the series of 637 patients with GPA of Mayo-Clinic) [9].
In addition, some sporadic cases of other endocrine disorders were reported during GPA, namely: Pan-hypopituitarism related to a diffuse infiltration of the anterior pituitary gland by granulomas, objectified by imagery and responsible for irretrievable destruction of the gland even after adequate corticosteroid and immunosuppressive treatment $[3,5,6,10]$.

This granulomatous hypophysitis specific for GPA may be responsible for a complete or dissociated hypophyseal insufficiency depending on the localization of the granulomas in the gland $[11,12]$. This specific granulomatous hypophysitis was confirmed by histological exam in rare cases, and sectoral involvement would be associated with a better prognosis because of the possibility of total functional recovery after systemic corticosteroid treatment $[11,13]$.

Adrenal gland involvement with adrenal granulomatous vasculitis during systemic GPA (associated with pulmonary and renal involvement) which has evolved favorably after systemic corticosteroids and cyclophosphamide [14]. Similarly, a fatal adrenal localization of GPA was reported by Thomas GO et al. [15].

Testicular involvement both in adult and pediatric forms of GPA [16-18].

Primary hyperparathyroidism or more classically hyperparathyroidism-like presentation related to hypercalcemia by ectopic activation of vitamin $\mathrm{D}$ due to the activated macrophages of GPA granulomas [19,20].

Type 1 diabetes mellitus [21,22]. The Swedish study of Hemminki K. et al, based on Sweden's "multi-generation" registry, concluded that type 1 diabetes mellitus in progeny was significantly associated with 13 parental diseases including GPA with a Standardized Incidence Ratio (SIR) of 2.12 [23].

${ }^{\star}$ Correspondence to: Salem Bouomrani, Department of Internal Medicine, Military Hospital of Gabes, Gabes 6000, Tunisia, Tel: +00216 98977555; E-mail: salembouomrani@yahoo.fr

Key words: Endocine system, Gland, Granulomatosis with polyangeiitis, GPA, Vasculitis, Autoimmunity

Received: March 22, 2018; Accepted: April 11, 2018; Published: April 14, 2018 
A hyper-prolactinemia most often moderate and associated with pituitary involvement related to the compression of the pituitary stalk by GPA granulomas $[3,6]$.

Thyroid disease: unusual and reported only as sporadic cases. Hypothyroidism is extremely rare during GPA: 1 case in the series of 77 patients with GPA of Cordier JF et al. [4,24-26]. Similarly, the frequency of hyperthyroidism during GPA is estimated at $\approx 1 \%$ [27].

\section{Mechanisms of endocrine involvement during GPA \\ Endocrine involvement during GPA can result from two main mechanisms [4]}

A direct damage of the glandular parenchyma by the granulomatous vasculitis this specific endocrine involvement of GPA was reported for the first time by Thomas GO and Lewis RJ in 1979 on the autopsy findings of a man who died after an adrenal haemorrhagic infarction complicating an active GPA. Granulomatous angiitis was objectified in adrenal and thyroid glands [15]. Since then, only a few sporadic cases confirmed histologically were reported.

Khalifa $\mathrm{M}$ et al [4], reported an interesting case of a 56-year-old woman with GPA in its limited form (sinusitis and pulmonary nodules) who was diagnosed with a thyroid cold nodule of $3 \mathrm{~cm}$ discovered on physical examination and confirmed by ultrasound and scintigraphy. The thyroid function tests were normal (TSH at 1.31 mui/l and FT4 at $12.3 \mathrm{pg} / \mathrm{ml}$ ) and the anti-thyroid antibodies were negative. Puncture was inconclusive and histological examination of the subtotal thyroidectomy specimen demonstrated necrotizing vasculitis with perivascular giant cell granulomas consistent with a thyroid localization of GPA. Van Durme C et al, reported the original finding of multiple endocrine diseases with central diabetes insipidus, hypogonadotropic hypogonadism, hyperprolactinemia, and hyperthyroidism in a 48-year-old woman with GPA. The PET-scan demonstrated a simultaneous increased uptake in the pituitary gland, nostrils, left lung and the left lobe of the thyroid gland. Thyroid cytopuncture confirmed vascular inflammation and the presence of GPA-specific giant cell granulomas. Thyroid dysfunction had normalized after corticosteroid and immunosuppressive treatment of GPA [3].

\section{An association between two autoimmune diseases}

These associations are in favour of the autoimmune origin of GPA, the dys-immune character common to GPA and autoimmune endocrine diseases (Hashimoto thyroiditis, Grave's disease, type 1 diabetes mellitus,..), and a similar predisposing genetic background [21,22,28-31].

Finally, it's important to note the specific cases of antithyroid drugs (propylthiouracil (PTU) and methimazole (MMI) -induced GPA during the treatment of hyperthyroidism and in particular Grave's disease [32]. It is estimated that $\approx 25 \%$ of patients with PTUtreated Grave's disease will develop ANCA antibodies and some of these patients will develop true ANCA-associated systemic vasculitis including GPA [33,34].

\section{Conclusion}

Despite their apparent rarity, the endocrine involvement during granulomatosis with polyangiitis is important to know and sometimes even to look for systematically because it sign the generalized character of this vasculitis. The endocrine disorders associated with GPA are by far dominated by central diabetes insipidus, and are most often related to a specific localization of granulomatous vasculitis in the endocrine glands. More rarely it may be an association with autoimmune endocrinopathies because of the autoimmune nature of this vasculitis (ANCA-associated angeiitis).

\section{Conflicts of interest}

No conflicts.

\section{References}

1. Holl-Ulrich K (2014) Vasculitis: New nomenclature of the Chapel Hill consensus conference 2012. Z Rheumatol 73: 823-833. [Crossref]

2. Karras A, Guiard E, Levi C, Thervet E (2012) Granulomatosis with polyangiitis (Wegener's granulomatosis). Presse Med 41: 1014-1023. [Crossref]

3. van Durme CM, Kisters JM, van Paassen P, van Etten RW, Tervaert JW (2011) Multiple endocrine abnormalities. Lancet 378: 540. [Crossref]

4. Khalifa M, BenFredj H, Ghannouchi N, Sriha B, Letaief A, et al. (2009) Thyroid involvement in Wegener's granulomatosis: a case report. Rev Med Interne 30: 176178. [Crossref]

5. Garovic VD, Clarke BL, Chilson TS, Specks U (2001) Diabetes insipidus and anterior pituitary insufficiency as presenting features of Wegener's granulomatosis. $\mathrm{Am} \mathrm{J}$ Kidney Dis 37: E5. [Crossref]

6. Santoro SG, Guida AH, Furioso AE, Glikman P, Rogozinski AS (2011) Panhypopituitarism due to Wegener's granulomatosis. Arq Bras Endocrinol Metabol 55: 481-485. [Crossref]

7. Al-Fakhouri A, Manadan A, Gan J, Sreih AG (2014) Central diabetes insipidus as the presenting symptom of granulomatosis with polyangiitis. J Clin Rheumatol 20: 151154. [Crossref]

8. De Parisot A, Puéchal X, Langrand C, Raverot G, Gil H, et al (2015) Pituitary involvement in granulomatosis with polyangiitis: report of 9 patients and review of the literature. Medicine (Baltimore) 94: e748. [Crossref]

9. Kapoor E, Cartin-Ceba R, Specks U, Leavitt J, Erickson B, et al. (2014) Pituitary dysfunction in granulomatosis with polyangiitis: The Mayo Clinic experience. $J$ Clin Endocrinol Metab 99: 3988-3994. [Crossref]

10. Slabu H, Arnason T (2013) Pituitary granulomatosis with polyangiitis. BMJ Case Rep 2013. [Crossref]

11. Goyal M, Kucharczyk W, Keystone E (2000) Granulomatous hypophysitis due to Wegener's granulomatosis. AJNR Am J Neuroradiol 21: 1466-1469. [Crossref]

12. Pereira EA, Plaha P, Hofer M, Karavitaki N, Cudlip SA (2013) Hypophyseal Wegener's granulomatosis presenting by visual field constriction without hypopituitarism. Clin Neurol Neurosurg 115: 762-764. [Crossref]

13. Cruz VB, Prayson RA (2014) Acute central hypothyroidism, diabetes insipidus and central hypogonadism in a 36-year-old woman. Neuropathology 34: 318-321. [Crossref]

14. Zagdanska J, Krakowka P, Walecki J (1989) Wegener's granulomatosis with adrenal gland involvement. Pneumonol Pol 57: 134-139. [Crossref]

15. Thomas GO, Lewis RJ (1979) Adrenal infarction: an unusual complication of Wegner's granulomatosis. Br J Dis Chest 73: 178-180. [Crossref]

16. Paik ML, MacLennan GT, Seftel AD (1999) Embolic testicular infarction secondary to nonbacterial thrombotic endocarditis in Wegener's granulomatosis. J Urol 161: 919920. [Crossref]

17. Agraharkar M, Gokhale S, Gupta R (2002) Wegener's granulomatosis diagnosed by testicular biopsy. Int Urol Nephrol 34: 559-564. [Crossref]

18. Barber TD, Al-Omar O, Poulik J, McLorie GA (2006) Testicular infarction in a 12-year-old boy with Wegener's granulomatosis. Urology 67: 846. [Crossref]

19. Edelson GW, Talpos GB, Bone HG 3rd (1993) Hypercalcemia associated with Wegener's granulomatosis and hyperparathyroidism: etiology and management. Am J Nephrol 13: 275-277. [Crossref]

20. Shaker JL, Redlin KC, Warren GV, Findling JW (1994) Case report: hypercalcemia with inappropriate 1,25-dihydroxyvitamin $\mathrm{D}$ in Wegener's granulomatosis. Am J Med Sci 308: 115-118. [Crossref]

21. Lorini R, Alibrandi A, Ravelli A, d'Annunzio G, Castelnuovo P, et al. (1999) Wegener's granulomatosis presenting with life-threatening pulmonary hemorrhage in a boy with type 1 diabetes. Diabetes Care 22: 1591-1592. [Crossref] 
22. Sugimoto A, Sugimoto S, Tanaka M, Kuribayashi T, Takemura J, et al. (1989) Wegener's granulomatosis (WG) and insulin dependent diabetes mellitus (IDDM). Jpn J Med 28: 374-378. [Crossref]

23. Hemminki K, Li X, Sundquist J, Sundquist K (2009) Familial association between type 1 diabetes and other autoimmune and related diseases. Diabetologia 52: 1820-1828. [Crossref]

24. Villa ML, Mukherjee JJ, Tran NQ, Cheah WK, Howe HS, et al. (2004) Anaplastic thyroid carcinoma with destructive thyrotoxicosis in a patient with preexisting multinodular goiter. Thyroid 14: 227-230. [Crossref]

25. Schuerwegh AJ, Verhelst J, Slabbynck H, Kockx MM, Coolen D (2007) Wegener's granulomatosis presenting as a thyroid mass. Clin Rheumatol 26: 454-456. [Crossref]

26. Cordier JF, Valeyre D, Guillevin L, Loire R, Brechot JM (1990) Pulmonary Wegener's granulomatosis. A clinical and imaging study of 77 cases. Chest 97: 906-912. [Crossref]

27. Olia MB, Halvani A (2006) Graves' Disease as the initial manifestation of Wegener's granulomatosis: A case report. Tanaffos 5: 75-8.

28. Fukui S, Iwamoto N, Tsuji S, Umeda M, Nishino A, et al. (2015) Diffuse alveolar hemorrhage emerging one week after starting high-dose corticosteroid therapy for granulomatosis with polyangiitis (GPA) with systemic lupus erythematosus (SLE). Intern Med 54: 2681-2686. [Crossref]
29. Douglas G, Bird K, Flume P, Silver R, Bolster M (2003) Wegener's granulomatosis in patients with rheumatoid arthritis. J Rheumatol 30: 2064-2069. [Crossref]

30. Aldasoro-Csceres V, Aldasoro-Caceres I, PerezMoreiras JV, Murie-Fernandez M, Ibanez-Bosch R (2014) CANCA positive necrotising scleritis and multiple sclerosis compatible with ocular Wegener: treatment with rituximab. Arch Soc Esp Oftalmol 89: 31-34. [Crossref]

31. Sieczkowska A, Lewandowski P, Szumera M, Kamiaska B (2011) Coexistence of Crohn disease and Wegener granulomatosis in a 15 -year-old patient. Med Wieku Rozwoj 15: 472-476. [Crossref]

32. Bonaci-Nikolic B, Nikolic MM, Andrejevic S, Zoric S, Bukilica M (2005) Antineutrophil cytoplasmic antibody (ANCA)-associated autoimmune diseases induced by antithyroid drugs: comparison with idiopathic ANCA vasculitides. Arthritis Res Ther 7: R1072-1081. [Crossref]

33. Gunton JE, Stiel J, Clifton-Bligh P, Wilmshurst E, McElduff A (2000) Prevalence of positive anti-neutrophil cytoplasmic antibody (ANCA) in patients receiving antithyroid medication. Eur J Endocrinol 142: 587. [Crossref]

34. Pillinger M, Staud R (1998) Wegener's granulomatosis in a patient receiving propylthiouracil for Graves' disease. Semin Arthritis Rheum 28: 124-129. [Crossref]

Copyright: @2018 Bouomrani S. This is an open-access article distributed under the terms of the Creative Commons Attribution License, which permits unrestricted use, distribution, and reproduction in any medium, provided the original author and source are credited. 